\title{
Combined Sulfur and Organic Compost Treatment Influences Nutrient Uptake and Photosynthetic Activity to Improve Growth and Yield of Sunflower
}

\section{Sami U1 Haq ${ }^{1}$, Abid Hussain ${ }^{1 *}$, Umair Riaz ${ }^{2}$, Muhammad Baqir Hussain ${ }^{1}$, Adnan Fareed ${ }^{1}$, Nabeel Ahmad Ikram $^{3}$ and Fahim Nawaz ${ }^{3}$}

${ }^{1}$ Department of Soil and Environmental Sciences, Muhammad Nawaz Shareef University of Agriculture Multan, 66000, Pakistan; ${ }^{2}$ Soil and Water Testing Laboratory for Research, Bahawalpur, 63100, Pakistan; ${ }^{3}$ Department of Agronomy, Muhammad Nawaz Shareef University of Agriculture, Multan, Pakistan.

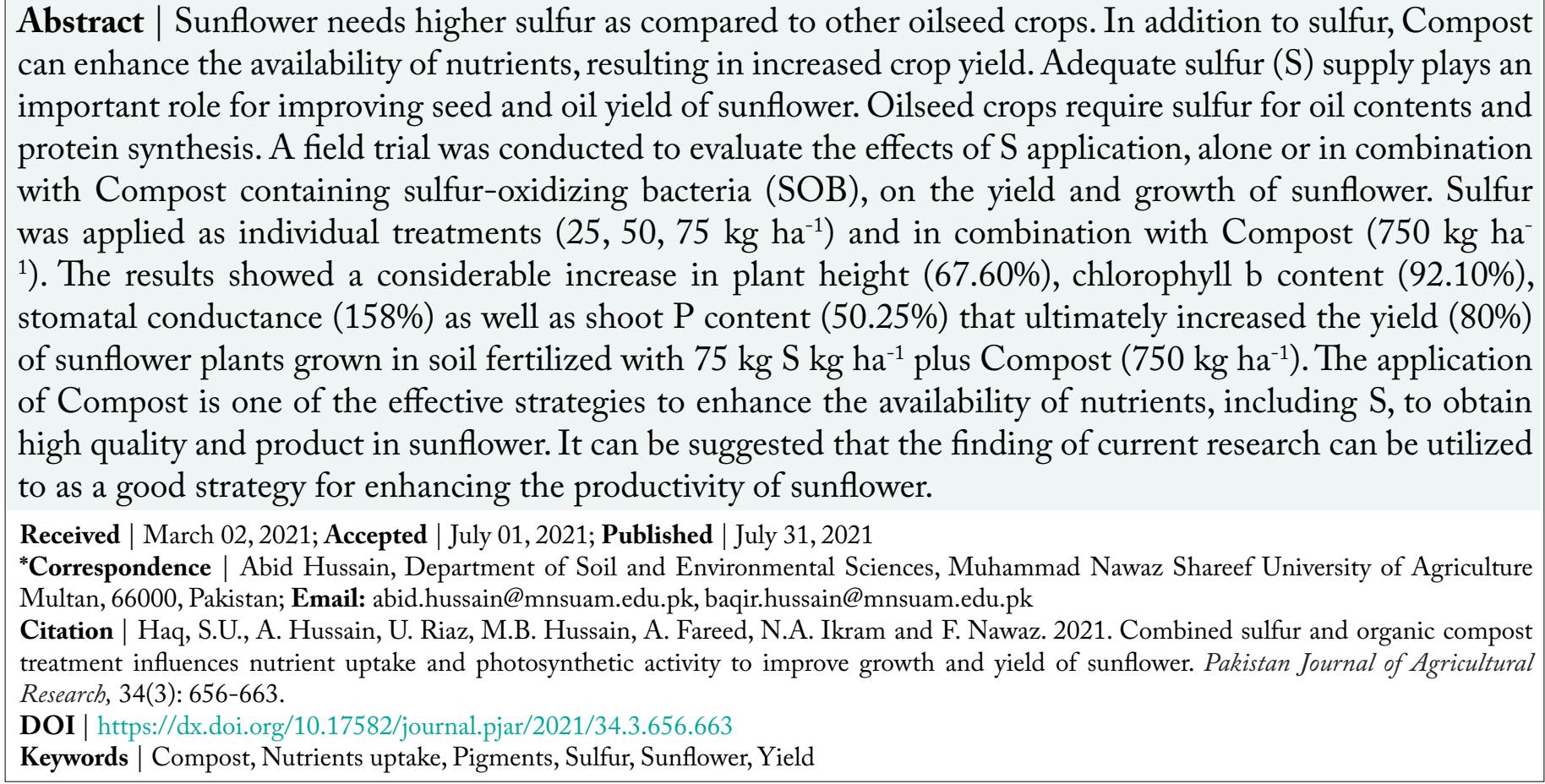

\section{Introduction}

Sunflower is grown worldwide as an edible oil crop

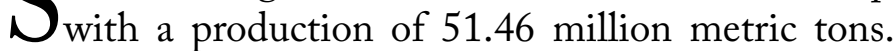
The high-quality seed contains $50 \%$ oil and 15 to $21 \%$ protein (Koubaa et al., 2016). Ukraine, Russia, the European Union, and Argentina are the leading sunflower producers (Fernández-Martínez et al., 2010). The average sunflower production is 1.3 tons $\mathrm{ha}^{-1}$ in Pakistan, while the production in Russia and other countries is 1.45 tons ha $^{-1}$ (Semerci et al., 2011)
(Sher et al., 2018). Sunflower is a high potential cash crop having a good value of edible oil. This crop gives a higher net and gross income than any other single crop (Panković et al., 2007). The optimal temperature for the ideal growth of sunflower is 20 to $25^{\circ} \mathrm{C}$; no doubt, it can also bear weather from 8 to $34^{\circ} \mathrm{C}$. Sunflower can be grown both in rain-fed and irrigation conditions. Sunflower ranked fourth in vegetable oil after soybean, canola, and palm. Sunflower seed is edible, and oil is quite palatable (Kumar et al., 2013). The major problem for low productivity is that the 
deficiency of nutrients, which needs to be addressed.

Sulfur (S) plays a crucial role in protein synthesis, primary and secondary metabolism in plants. Sulfur can be increased the concentration in plants and also helps to mitigate the effects of abiotic stresses. The increased concentration of Sin plants helps to mitigate the adverse effects of abiotic stresses. It may also function as a hormone to control cell growth and differentiation (Droux, 2004). Sulfur is required to attain high biological and grain yield, harvest index, and oil content. The content of oilseed significantly increased by the supply of $\mathrm{S}$ and Compost in groundnut (Pattanayak et al., 2017). Its application improves soil health, including cation exchange capacity, nutrient supply, $\mathrm{pH}$, water retention, and structure. The composting material with acidic $\mathrm{pH}$ can play a significant role in the enhancement of soil nutrition (Abujabhah et al., 2016). The concentration of extractable nutrients is widely used to assess the impact of compost addition on nutrient availability. Composted organic fertilizer showed a significant improvement in biochemical and physical parameters in plants, which improve the organic content of the soil (Seiler, 1992). Organic waste is one of the traditional and old methods to increase crop growth and production (Wong et al., 1999). Compost can increase the plant height but the number of grains per plant, leaf thickness and stem girth can be decreased with late sowing (Aggelides and Londra, 2000). Keeping in view the problem of sunflower production, it was observed that studies related to understanding the effects of combined $\mathrm{S}$ and S-oxidizing bacteria (SOB) enriched compost application are scant. So, present study aimed to identify the optimum $\mathrm{S}$ fertilizer levels to improve the growth and yield of sunflower to enhance the nutrient use efficiency, especially sulfur by the addition of Compost.

\section{Materials and Methods}

\section{Experimental design and crop busbandry}

The experiment was carried out at the farm of Muhammad Nawaz ShareefUniversity of Agriculture, Multan, on 0.753 kanals (15 Marla's)(Table 1). The selected variant of sunflower (Hysun-33) was sown on 07.02.2019. The experimental study was done by following Randomized Complete Block Design (RCBD). The design was having three replications and eight treatments. The total number of blocks was 24 . The land was deeply ploughed with planking to make the soil pulverized, smooth and reliable. In the previous crop, stubbles were removed from the field. The total deuration of crop was 3 months, however the cultural practices were done to control the insect pest and disease during these 3 months. Weeds were eradicated by manual hoening method.

\section{Metrological data}

The monthly average temperature during 2019 was acquired from the Meteorological Observatory of MNS-UAM. In February, the maximum and minimum average temperatures were $19^{\circ} \mathrm{C}$ and $10^{\circ} \mathrm{C}$. In March, the highest and lowest average temperature was $24^{\circ} \mathrm{C}$ and $15^{\circ} \mathrm{C}$. In April, the maximum average temperature was $35^{\circ} \mathrm{C}$, and the minimum average temperature was $23^{\circ} \mathrm{C}$. While in May, the highest temperature was $37.2^{\circ} \mathrm{C}$, and the lowest temperature was $25.8^{\circ} \mathrm{C}$. June was the hottest month with a maximum temperature of $39.9^{\circ} \mathrm{C}$ and a minimum of $29.2^{\circ} \mathrm{C}$ (Figure 1$)$.

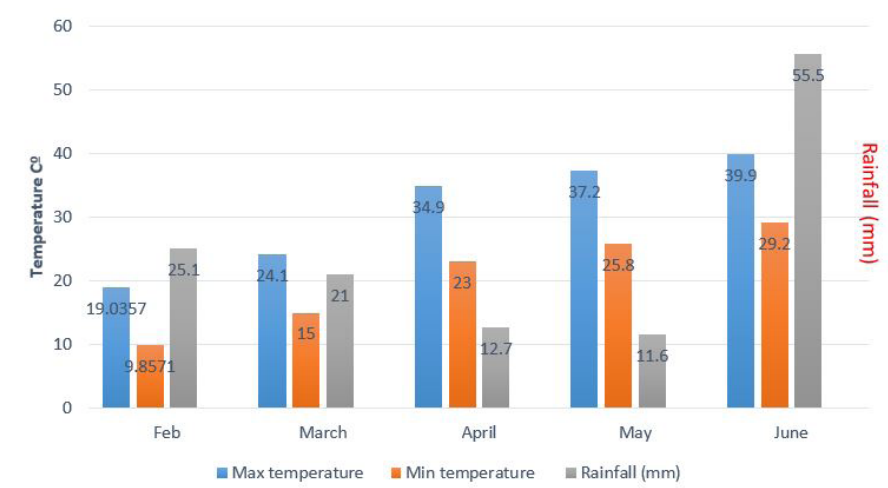

Figure 1: Monthly average temperature ${ }^{\circ} \mathrm{C}$ and rainfall $(\mathrm{mm})$ during 2019.

\section{Plant materials and growth condition}

The aerobic Compost and sulfur were applied in the field as per the treatment plan. Sunflower hybrid (Hysun-33) was sown with inter-row distance and distance between plants 75 and $25 \mathrm{~cm}$, respectively. In this experiment, a randomized complete block design (RCBD) was adopted with three treatment replications. The Compost containing SOD was obtained from Soil Microbiology and Biochemistry Lab., Institute of Soil and Environmental Sciences, University of Agriculture Faisalabad (ISES, UAF). The recommended doses of $\mathrm{N}: \mathrm{P}_{2} \mathrm{O}_{5}: \mathrm{K}_{2} \mathrm{O}$ (118:84:62 $\left.\mathrm{kg} \mathrm{ha} \mathrm{h}^{-1}\right)$ were applied. The seed rate of sunflower (10 $\mathrm{kg} \mathrm{ha}^{-1}$ ) was used for sowing purposes. The net size of each plot was $8 \mathrm{ft}$. $\times 7.5 \mathrm{ft}$.

\section{Treatment combinations}

The treatments included (T0) control having no 
amendment, (T1) SOB inoculated compost at the rate of $750 \mathrm{~kg} \mathrm{ha}^{-1}$,(T2) Sulfur at the dose of $25 \mathrm{~kg}$ ha ${ }^{-1}$, (T3) Sulfur dose of $50 \mathrm{~kg} \mathrm{ha}^{-1}$, (T4) Sulfur dose of $75 \mathrm{~kg} \mathrm{ha}{ }^{-1}$, (T5) SOB enriched compost at the dose of $750 \mathrm{~kg} \mathrm{ha}^{-1}$ and sulfur at the dose of $25 \mathrm{~kg} \mathrm{ha}^{-1}$, (T6) SOB enriched compost at the dose of $750 \mathrm{~kg} \mathrm{ha}^{-1}$ and sulfur at the dose of $50 \mathrm{~kg} \mathrm{ha}^{-1}$, (T7) SOB enriched compost at the dose of $750 \mathrm{~kg} \mathrm{ha}^{-1}$ and sulfur at the dose of $75 \mathrm{~kg} \mathrm{ha}{ }^{-1}$. Elemental sulfur is the source of sulfur that we are applied in our research trial.

\section{Gaseous exchange measurements}

At the flowering stage, the gaseous exchange parameters such as transpiration rate $\left(\mathrm{mmol} \mathrm{H}_{2} \mathrm{O} \mathrm{m}^{-2}\right.$ $\left.\mathrm{s}^{-1}\right)$, sub-stomatal conductance $\left(\mathrm{mmol} \mathrm{H}_{2} \mathrm{O} \mathrm{m}^{-2} \mathrm{~s}^{-1}\right)$, photosynthetic rate $\left(\mu \mathrm{mol} \mathrm{CO} \mathrm{m}^{-2} \mathrm{~s}^{-1}\right)$ and stomatal conductance $\left(\mathrm{mmol} \mathrm{H} \mathrm{O} \mathrm{m}^{-2} \mathrm{~s}^{-1}\right)$ of an uppermost fully expanded leaf were recorded, using portable photosynthesis system CIRAS-3 (P.P. Systems, Amesbury, USA). The chamber was adjusted at $\mathrm{mL}$ $\mathrm{min}^{-1}$ airflow rate, $1200 \mu \mathrm{mol} \mathrm{m} \mathrm{m}^{-2} \mathrm{~s}^{-1}$ density of photosynthetic photon flux, $390 \pm 5 \mu \mathrm{mol} \mathrm{mol}^{-1} \mathrm{CO}_{2}$ concentration rate, $99.9 \mathrm{kPa}$ atmospheric pressure.

\section{Chlorophyll pigments analysis}

The fresh leaf sample $(0.5 \mathrm{~g})$ was mixed in a $5 \mathrm{~mL}$ acetone solution. The mixture was filtered through Whatman filter paper No.1 and centrifuged at 9000 rpm for 5 minutes at room temperature. The resultant filtrate was measured at different wavelengths on Spectrophotometer for Chlorophyll a $(663 \mathrm{~nm})$, chlorophyll b $(645 \mathrm{~nm})$, and carotenoids $(480 \mathrm{~nm})$, respectively.

\section{Yield and yield components}

The harvest index was calculated by formula achene yield divided by biological yield. At the maturity of the crop, samples from each treatment plot were collected. The number of seeds per pod, number of pods per plot and thousand achene weight (grams) was recorded from the square meter of the property. The random counting measured the number of seed per pod in mature pods, and the average number of grains was noted. For calculation of 1000-achene weight, 1000-achene were weighed three times, and the average was counted. The number of pods per plant was calculated from the average of samples. The biological yield can be obtained by weighing the whole plants from a $1 \mathrm{~m}^{2}$ area and converted into tons $\mathrm{ha}^{-1}$. The outcome of achenes was also determined by considering the total achenes in the $1 \mathrm{~m}^{2}$ area.

$$
\text { Harvest Index }=\frac{\text { achene yield }}{\text { biological yield }}
$$

\section{Sulfur analysis}

Take $(1 \mathrm{mg})$ of nitric acid solution, and $(500 \mathrm{ml})$ of Hydrochloric acid in $(300 \mathrm{ml})$ of water. Gelatin was taken (0.6) grams, dissolved in $(200 \mathrm{ml})$ solution and allowed the solution to stand at $40^{\circ} \mathrm{C}$. After 16-18 hours, brought the semi gelatinous fluid to room temperature. After that barium chloride was taken (2 $\mathrm{g})$, stir the solution until the solution can be dissolved. Plant material was taken $(0.25)$ grams, nitric acid was taken $(3 \mathrm{ml})$ in $(100 \mathrm{ml})$ volumetric flask. Per chloric acid was taken $(2 \mathrm{ml})$ and heat the flask on a hot plate until the white fumes can appear. The flask should be cool at room temperature and hydrochloric acid was taken $(3 \mathrm{ml})$ and make the solution to $(100 \mathrm{ml})$ by the addition of water.

\section{Nutrient analysis}

Macronutrient (N-P-K) analysis was done on a dry weight basis. The shoots and leaves of the sunflower were collected and oven-dried at $65{ }^{\circ} \mathrm{C}$ for 72 hours. The dried sample was finely ground for NPK determination accumulated in the shoot and leaves of the plants. The digestion tube was filled with 5 $\mathrm{mL}$ concentrated $\mathrm{H}_{2} \mathrm{SO}_{4}, 0.3 \mathrm{~g}$ finely ground plant samples, and $2 \mathrm{~mL} \mathrm{H}_{2} \mathrm{O}_{2}$. Leaves were heated at $350{ }^{\circ} \mathrm{C}$ for three hours until the solution became colorless. Post digestion cooling was done to bring the temperature of the solution to room temperature, and a final volume of $50 \mathrm{ml}$ was made using distilled water. Later, the Kjeldahl method was used to analyse $\mathrm{N}$ content in the shoot. However, Vanadium molybdate yellow calorimetric method was used for flame photometer (Sherwood M410, U.K.) (Wolf, 1982).

Table 1: Analysis of soil samples obtained from the experimental site before sowing.

$\begin{array}{lll}\text { Parameter } & \text { Units } & \text { Values } \\ \mathrm{EC}_{1: 5} & \mathrm{dS} \mathrm{m}{ }^{-1} & 2.47 \\ \mathrm{pH}_{1: 5} & & 8.10 \\ \text { Organic Matter } & \% & 0.79 \\ \text { Total N } & \mathrm{mg} \mathrm{kg}^{-1} & 102 \\ \text { Available P } & \mathrm{mg} \mathrm{kg}^{-1} & 8.50 \\ \text { Available K } & \mathrm{mg} \mathrm{kg}^{-1} & 240 \\ \text { Saturation } & \% & 36 \\ \text { Sulfur } & \% & 1.91\end{array}$

Values are the average of three samples. 
Statistical analysis

The data collected and analyzed statistically by using Statistix-8.1 and Fisher's method analysis of variance (ANOVA). Treatment's mean was compared by the LSD test at a 5\% probability level (Steel and Torrie, 1980).

\section{Results and Discussion}

\section{Photosynthetic pigments}

Sulfur and Compost significantly influenced the Chlorophyll a, chlorophyll b, and carotenoids of Sunflower (Table 2). The sulfur and SOB enriched compost application resulted in insignificance $(p \leq$ $0.05)$ differences in Chlorophyll $\mathrm{a}, \mathrm{b}$ and Carotenoids. Chlorophyll a (58.06\%), Chlorophyll b (92.10\%) and Carotenoids was observed (25.74\%) and this can be increase with the application of compost @ $750 \mathrm{~kg} \mathrm{ha}^{-1}$ and sulfur@ $75 \mathrm{~kg} \mathrm{ha}^{-1}$ (T7) as compared to control means no sulfur application. The application of sulfur @ $25 \mathrm{~kg} \mathrm{ha}^{-1}$ (T1), minimum chlorophyll a, chlorophyll $\mathrm{b}$, and carotenoids decreased by $9.67 \%, 15.78 \%$, and $5.38 \%$, respectively, yet were still higher than regulation. The units of Chlorophyll a, Chlorophyll $b$ and Carotenoids are shown in (Table 2).

Table 2: Effects of sulfur and sulfur-oxidizing bacteria enriched compost on photosynthetic pigments.

$\begin{array}{llll}\begin{array}{l}\text { Treat } \\ \text { ment }\end{array} & \begin{array}{l}\text { Chlorophyll a } \\ \left(\mathrm{mg} \mathrm{g}^{-1} \mathrm{FW}\right)\end{array} & \begin{array}{l}\text { Chlorophyll b } \\ \left(\mathrm{mg} \mathrm{g}^{-1} \mathrm{FW}\right)\end{array} & \begin{array}{l}\text { Carotenoids } \\ \left(\mathbf{u g ~ g}^{-1} \mathrm{KW}\right)\end{array} \\ \text { T0 } & 0.62 \pm 0.01^{\mathrm{h}} & 0.38 \pm 0.02^{\mathrm{h}} & 3.34 \pm 0.04^{\mathrm{g}} \\ \text { T1 } & 0.68 \pm 0.01^{\mathrm{g}} & 0.44 \pm 0.01^{\mathrm{g}} & 3.52 \pm 0.04^{\mathrm{f}} \\ \text { T2 } & 0.73 \pm 0.01^{\mathrm{f}} & 0.49 \pm 0.01^{\mathrm{f}} & 3.74 \pm 0.04^{\mathrm{e}} \\ \text { T3 } & 0.78 \pm 0.01^{\mathrm{e}} & 0.55 \pm 0.02^{\mathrm{e}} & 3.93 \pm 0.05^{\mathrm{d}} \\ \text { T4 } & 0.82 \pm 0.01^{\mathrm{d}} & 0.61 \pm 0.01^{\mathrm{d}} & 4.10 \pm 0.04^{\mathrm{c}} \\ \text { T5 } & 0.89 \pm 0.01^{\mathrm{c}} & 0.64 \pm 0.01^{\mathrm{c}} & 4.2 \pm 0.03^{\mathrm{b}} \\ \text { T6 } & 0.94 \pm 0.01^{\mathrm{b}} & 0.68 \pm 0.01^{\mathrm{b}} & 4.4 \pm 0.03^{\mathrm{a}} \\ \text { T7 } & 0.98 \pm 0.01^{\mathrm{a}} & 0.73 \pm 0.02^{\mathrm{a}} & 4.2 \pm 0.10^{\mathrm{b}} \\ \text { LSD } & 0.37 & 0.02 & 0.08\end{array}$

The columns sharing the same letter are non-significant, Control (TO), SOB enriched compost@750 kg ba-1 (T1),Sulfur@25 kg ba-1 (T2),Sulfur@50 kg ba-1 (T3),Sulfur@ $75^{\mathrm{kg} b a-1}$ (T4), SOB enriched compost@750 kg ha-1 and sulfur @ $25^{\mathrm{kg} b a-1}$ (T5), SOB enriched compost@750 kg ba-1 and sulfur@50 kg ba-1 (T6), SOB enriched

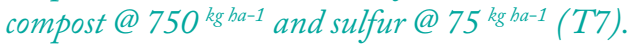

\section{Gaseous exchange}

Application of sulfur and Compost significantly $(p \leq$ 0.05 ) influenced Gaseous exchange measurements, i.e., transpiration rate $(E)$, photosynthetic $(A)$, sub stomatal conductance $\left(C_{i}\right)$, and Stomatal conductance $\left(g_{s}\right)$ (Table 3). The highest increase in $E(132 \%), A$ (85\%), $C_{i}(57.52 \%)$ and $g_{s}(158 \%)$. The measurements of gaseous exchange significantly improved with the application of compost @ $750 \mathrm{~kg} \mathrm{acre}{ }^{-1}$ and sulfur @ $75 \mathrm{~kg} \mathrm{ha}^{-1}$ (T7) while Stomatal conductance increase with the application of Compost @ $750 \mathrm{~kg} \mathrm{ha} \mathrm{ha}^{-1}$ and sulfur @20 kg ha-1 (T6) as compared to control that decrease in gaseous exchange meaurments. The minimum decrease in Transpiration rate $68.08 \%$, Photosynthetic rate 48.80 , Sub stomatal conductance $33.62 \%$ and Stomatal conductance $88.07 \%$ respectively decrease with the dose of sulfur @ $25 \mathrm{~kg}$ ha -1 (T1) but increase than control which means no sulfur was applied (Table 3 ).

\section{Yield and yield attributes}

The compost and sulfur application significantly $(p \leq 0.05)$ affected the yield, yield attributes including thousand achene weight, plant height, biological yield, achene yield, and harvest index (Table 4). The maximum thousand achene weight, Plant Height, Achene yield, harvest index and biological yield was recorded 55.75\%, 67.60, 80.37\%, 8.60\%, and $62.08 \%$, respectively improved with the application of Compost@750 kg ha-1, and sulfur@ $75 \mathrm{~kg} \mathrm{ha}^{-1}$ (T7) compared to control (no Sulfur and Compost apply). The lowest thousand achene weight (50.32\%), Plant Height (43.66\%), Achene yield (36.07\%), Biological yield (5.88\%) and Harvest index was recorded (44.51\%) decrease with the dose of sulfur@ $25 \mathrm{~kg}$ $\mathrm{ha}^{-1}$ (T1) but increase than control that is decrease in yield attributes (Table 4).

\section{Nutrient analysis}

The application of sulfur and Compost can be significantly $(p \leq 0.05)$ affected the accumulation of plant nutrients viz. nitrogen $(\mathrm{N})$, phosphorus $(\mathrm{P})$ and potassium (K) content (Table 5). The entire shoot $\mathrm{N}$ content $(24.83 \%)$ was recorded in treated plant with Compost at $300 \mathrm{~kg} \mathrm{acre}^{-1}$ and sulfur at $10 \mathrm{~kg} \mathrm{acre}^{-1}$ while shooting P (50.25 \%) and shoot K content (44.72\%) improved with the application of Compost@ 950 $\mathrm{kg} \mathrm{ha}{ }^{-1}$ and sulfur @ $20 \mathrm{~kg} \mathrm{ha}^{-1}$ (T6) comparatively increase to control (no Sulfur and Compost apply). The lowest shoot nitrogen content, shoot phosphorus content and shoot potassium content was recorded at $22.41 \%, 40.77 \%$, and $39.76 \%$, respectively, decreasing with the dose of sulfur@ $25 \mathrm{~kg} \mathrm{ha}^{-1}$ (T1) but increase than control that is no sulfur and compost was applied (Table 5). 
Table 3: Effects of sulfur and Compost on Gaseous exchange.

$\begin{array}{lllll}\text { Treatment } & \begin{array}{l}\text { Transpiration rate } \\ \left(\mathrm{mmol} \mathrm{CO}_{2} \mathrm{~m}^{-2} \mathrm{~s}^{-1}\right)\end{array} & \begin{array}{l}\text { Photosynthetic rate } \\ \left(\mu \mathrm{mol} \mathrm{CO} \mathbf{m}^{-2} \mathrm{~s}^{-1}\right)\end{array} & \begin{array}{l}\text { Sub stomatal conductance } \\ \left(\mathrm{H}_{2} \mathrm{O} \mathrm{m}^{-2} \mathbf{s}^{-1}\right)\end{array} & \begin{array}{l}\text { Stomatal conductance } \\ \left(\mathrm{mmol} \mathrm{CO}_{2} \mathrm{~m}^{-2} \mathbf{s}^{-1}\right)\end{array} \\ \text { T0 } & 0.94 \pm 0.05^{\mathrm{e}} & 7.97 \pm 0.35^{\mathrm{e}} & 113 \pm 3.28^{\mathrm{d}} & 28 \pm 1.73^{\mathrm{d}} \\ \text { T1 } & 1.58 \pm 0.04^{\mathrm{c}} & 11.86 \pm 0.77^{\mathrm{bc}} & 151 \pm 4.81^{\mathrm{c}} & 52.66 \pm 4.10^{\mathrm{bc}} \\ \text { T2 } & 1.17 \pm 0.04^{\mathrm{d}} & 8.6 \pm 0.78^{\mathrm{de}} & 120 \pm 5.86^{\mathrm{d}} & 46 \pm 4.58^{\mathrm{c}} \\ \text { T3 } & 1.33 \pm 0.04^{\mathrm{d}} & 9.43 \pm 0.45^{\mathrm{de}} & 143 \pm 6.94^{\mathrm{c}} & 52.3 \pm 5.90^{\mathrm{bc}} \\ \text { T4 } & 1.62 \pm 0.06^{\mathrm{bc}} & 10.43 \pm 0.92^{\mathrm{cd}} & 147 \pm 9.87^{\mathrm{bc}} & 53.6 \pm 3.18^{\mathrm{bc}} \\ \text { T5 } & 1.8 \pm 0.09^{\mathrm{b}} & 13.06 \pm 0.33^{\mathrm{ab}} & 162 \pm 3.84^{\mathrm{ab}} & 65.3 \pm 5.93^{\mathrm{ab}} \\ \text { T6 } & 2.01 \pm 0.04^{\mathrm{a}} & 14.0 \pm 0.80^{\mathrm{a}} & 172 \pm 4.33^{\mathrm{a}} & 74 \pm 5.57^{\mathrm{a}} \\ \text { T7 } & 2.19 \pm 0.06^{\mathrm{a}} & 14.8 \pm 0.61^{\mathrm{a}} & 178 \pm 5.49^{\mathrm{a}} & 72.3 \pm 6.36^{\mathrm{a}} \\ \text { LSD } & 0.19 & 1.90 & 18.39 & 13.05\end{array}$

The columns sharing the same letter are non-significant, Control (TO),SOB enriched compost @750 kgha-1 (T1),Sulfur@25kgha-1 (T2), Sulfur

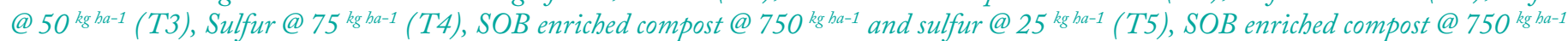
and sulfur@50 kg ha-1 (T6),SOB enriched compost@750 kg ba-1 and sulfur @ $75^{\mathrm{kg} g a-1}$ (T7).

Table 4: Effects of sulfur and Compost on Yield and Yield attributes.

$\begin{array}{llllll}\text { Treatment } & \begin{array}{l}\text { Thousand achene weights } \\ (\mathrm{g})\end{array} & \begin{array}{l}\text { Plant Height } \\ (\mathbf{c m})\end{array} & \begin{array}{l}\text { Achene yield } \\ \left(\mathbf{t ~ h a} \mathbf{1}^{-1}\right.\end{array} & \begin{array}{l}\text { Biological yield } \\ \left(\mathbf{t} \mathrm{ha}^{-1}\right)\end{array} & \begin{array}{l}\text { Harvest index } \\ (\%)\end{array} \\ \text { T0 } & 30.6 \pm 2.02^{\mathrm{d}} & 71 \pm 5.78^{\mathrm{e}} & 1.58 \pm 0.02 & 8.83 \pm 0.04^{\mathrm{d}} & 19.86 \pm 2.57^{\mathrm{f}} \\ \text { T1 } & 46 \pm 1.15^{\mathrm{a}} & 102 \pm 2.21^{\mathrm{bc}} & 2.15 \pm 0.28^{\mathrm{bc}} & 9.35 \pm 0.06^{\mathrm{abc}} & 28.7 \pm 0.55^{\mathrm{bc}} \\ \text { T2 } & 37.66 \pm 1.20^{\mathrm{c}} & 85.33 \pm 7.22^{\mathrm{d}} & 1.7 \pm 0.22^{\mathrm{d}} & 8.92 \pm 0.04^{\mathrm{cd}} & 22.91 \pm 1.54^{\mathrm{e}} \\ \text { T3 } & 39.33 \pm 2.60^{\mathrm{bc}} & 94.66 \pm 1.20^{\mathrm{cd}} & 1.84 \pm 0.27^{\mathrm{cd}} & 9.07 \pm 0.15^{\mathrm{bc}} & 25.01 \pm 1.39^{\mathrm{de}} \\ \text { T4 } & 42.33 \pm 2.90^{\mathrm{abc}} & 97.37 \pm 0.87^{\mathrm{bc}} & 1.93 \pm 0.31^{\mathrm{cd}} & 9.21 \pm 0.19^{\mathrm{abc}} & 26.86 \pm 1.33^{\mathrm{cd}} \\ \text { T5 } & 44.66 \pm 2.33^{\mathrm{ab}} & 110 \pm 1.15^{\mathrm{ab}} & 2.5 \pm 0.32^{\mathrm{ab}} & 9.46 \pm 0.03^{\mathrm{ab}} & 29.82 \pm 0.34^{\mathrm{ab}} \\ \text { T6 } & 46.66 \pm 0.88^{\mathrm{a}} & 115 \pm 2.18^{\mathrm{a}} & 2.74 \pm 0.16^{\mathrm{a}} & 9.54 \pm 0.05^{\mathrm{ab}} & 30.86 \pm 0.18^{\mathrm{ab}} \\ \text { T7 } & 47.66 \pm 0.88^{\mathrm{a}} & 119 \pm 3.51^{\mathrm{a}} & 2.85 \pm 0.07^{\mathrm{a}} & 9.59 \pm 0.02^{\mathrm{a}} & 32.19 \pm 0.34^{\mathrm{a}} \\ \text { LSD } & 5.60 & 2.11 & 0.44 & 0.18 & 2.50\end{array}$

The columns sharing the same letter are non-significant, Control (T0), SOB enriched compost @ 750 kg ba-1 (T1), Sulfur @25 kg ba-1 (T2), Sulfur

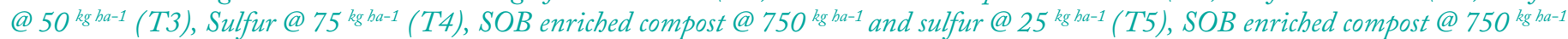
andsulfur@50 kg ba-1 (T6),SOB enriched compost@750 kg ha-1 and sulfur@75 kg ba-1 (T7).

Photosynthetic rates depend on photosynthetic pigments. A decrease in photosynthetic pigments due to osmotic stress means a reduction in photosynthesis. When the plant is treated with $\mathrm{Ca}+2$ and $\mathrm{K}+$, it increases in Chlorophyll a and chlorophyll b (Brestic et al., 2016). Sulfur increased Chlorophyll $a$ and chlorophyll $b$ are probably improved acidic conditions within the leaf due to high production (Rao and LeBlanc, 1966). Under acidic conditions in leaves, Chlorophyll a is hydrolyzed five times faster than Chlorophyll b. in the case of photosynthetic pigments, and sulfur availability is more than control. The application of sulfur increased photosynthetic pigments compared to control (Pružinská et al., 2003) (Table 2). Application of sulfur enhanced gaseous exchange characteristics (Anjum et al., 2011). Sulfur availability can also increase the photosynthetic rate. Under sulfur deficient conditions, the gaseous exchange parameters have been reported in maize, barley and rape (Kaschuk et al., 2009). In this study, the application of sulfur increased the photosynthetic rate. The application of sulfur improved the gaseous exchange characteristics as compared to control (Table 3 ). In our case, elemental sulfur produced a maximum of thousands of achene weight and control produced minimum achene weight (López-Bellido et al., 2006). The application of sulfur significantly increased plant height at 30 days after sowing. The application of sulfur can be increased the plant height which is due to metabolic process. It activated the plant cells, which increased the meristematic activities, causing more apical growth (Shekhawat and Shivay, 2012). The use of sulfur increased achene yield. Achene yield results from the combined effects of the different yield components, and variations in output are likely to occur. Due to sulphur levels, significant variations 
in achene yield were observed (Uz-Zaman et al., 2018). The maximum biological yield was obtained with sulfur compared to control (Kelly et al., 2017). Harvest index is an essential parameter of a crop to the transformation of photosynthetic yield into economic yield. The hybrid variety of Hysun 33 had a significant value of head diameter, harvest index, thousand seed weight, respectively. In the case of sulfur application, the yield can be increased as compared to control. (Montemurro et al., 2006) (Table 4). The sulfur status of plants directly affects the metabolism of primary macronutrients, mainly N. Proteins and amino acids are the byproducts of $\mathrm{N}$-assimilation. In our study, the application of $\mathrm{S}$ improves $\mathrm{N}$ uptake in plants. Plants have well organized sulfur and nitrogen pathways and are functionally convergent, so the availability of one nutrient regulates the other. Moreover, nitrate assimilation is closely related to $\mathrm{C}$ assimilation in plants that can results in reduced photosynthesis ultimately affecting plant growth (Murtaza et al., 2016). The application of sulfur can increase the uptake of macronutrients such as phosphorus, potash and nitrogen (Wu et al., 2005) (Table 5).

Table 5: Effects of sulfur and Compost on nutrient analysis.

$\begin{array}{llll}\begin{array}{l}\text { Treat- } \\ \text { ment }\end{array} & \begin{array}{l}\text { Shoot Nitrogen } \\ \text { Content } \\ (\mathrm{mg} / \mathrm{kg})\end{array} & \begin{array}{l}\text { Shoot Phospho- } \\ \text { rus Content } \\ (\mathrm{mg} / \mathrm{kg})\end{array} & \begin{array}{l}\text { Shoot Potassi- } \\ \text { um Content } \\ (\mathrm{mg} / \mathrm{kg})\end{array} \\ \text { T0 } & 55 \pm 3.05^{\mathrm{c}} & 11.6 \pm 0.52^{\mathrm{f}} & 53.66 \pm 2.90^{\mathrm{e}} \\ \mathrm{T} 1 & 67.33 \pm 0.88^{\mathrm{a}} & 16.33 \pm 0.40^{\mathrm{ab}} & 75 \pm 3.79^{\mathrm{ab}} \\ \mathrm{T} 2 & 55.66 \pm 1.20^{\mathrm{c}} & 12.6 \pm 0.64^{\mathrm{ef}} & 58 \pm 2.31^{\mathrm{de}} \\ \text { T3 } & 58.66 \pm 2.90^{\mathrm{bc}} & 13.93 \pm 0.35^{\mathrm{de}} & 64.33 \pm 3.76^{\mathrm{cd}} \\ \mathrm{T} 4 & 54.66 \pm 2.33^{\mathrm{c}} & 14.43 \pm 0.61^{\mathrm{cd}} & 68 \pm 2.89^{\mathrm{bc}} \\ \text { T5 } & 68.66 \pm 1.45^{\mathrm{a}} & 15.8 \pm 0.34^{\mathrm{bc}} & 73.33 \pm 3.18^{\mathrm{abc}} \\ \mathrm{T} 6 & 68.33 \pm 3.18^{\mathrm{a}} & 17.43 \pm 0.37^{\mathrm{a}} & 77.66 \pm 3.48^{\mathrm{a}} \\ \text { T7 } & 65.33 \pm 3.53^{\mathrm{ab}} & 16.2 \pm 0.30^{\mathrm{ab}} & 75.66 \pm 3.53^{\mathrm{ab}} \\ \text { LSD } & 7.37 & 1.43 & 9.30\end{array}$

The columns sharing the same letter are non-significant, Control (T0), SOB enriched compost @ $750 \mathrm{~kg} b a-1$ (T1), Sulfur @ $25^{\mathrm{kg} k a-1}$ (T2), Sulfur @ 50 kg ba-1 (T3), Sulfur@ $75^{\mathrm{kg} b a-1}$ (T4), SOB enriched compost@750 kg ba $a^{-1}$ and sulfur @ $25^{\mathrm{kg} h a-1}$ (T5), SOB enriched compost@750 kg ba-1 and sulfur @ $50^{\mathrm{kg} h a-1}$ (T6), SOB enriched compost@750 kg ba-1 and sulfur@75 kg ba-1 (T7).

\section{Conclusions and Recommendations}

The combined application of sulfur and Compost gave high-performance results. The application of inorganic and organic nutrients is essential to attain sustainability in oil and seed production. Acidic
Compost improved the accessibility of inorganic sources, resulting in a synergistic role in plants' biochemical and physiological processes that can increase the production; however, its combined effect may also be tested in salt-affected soils. Sunflower is photo-insensitivity, short duration and broad adaptation to agro-climatic regions of soil. The amendement of Sulphur with the combination of compost significantly improved the yield attributes of sunflower which ultimately can enhance the production of oil seed crops. The enhancement in the production of oil seed crops will lead to the raised GDP of Pakistan.

\section{Acknowledgements}

All the authors are thankful to the Muhammad Nawaz Shareef University of Agriculture Multan for providing lab facilities (central lab) and (Soil lab).

\section{Novelty Statement}

The combined effect of Sulphur and compost enhance the nutrient use efficiency and yield of sunflower. The amendment of this novel combination improved the achene yield up to $80 \%$.

\section{Author's Contribution}

AH: Supervised the research and field trials activities. FN and MBH: Assisted in the analysis of different nutrients.

UR, NI and AF: Contributed to the writing of this manuscript.

\section{Conflict of interest}

The authors have declared no conflict of interest.

\section{References}

Abujabhah, I.S., S.A. Bound, R. Doyle and J.P. Bowman. 2016. Effects of biochar and compost amendments on soil physico-chemical properties and the total community within a temperate agricultural soil. Appl. Soil Ecol., 98: 243-253. https://doi.org/10.1016/j. apsoil.2015.10.021

Aggelides, S.M. and P.A. Londra. 2000. Effects of Compost produced from town wastes and sewage sludge on the physical properties of loamy and clay soil. Bioresour. Technol., 71: 
253-259. https://doi.org/10.1016/S09608524(99)00074-7

Anjum, S.A., L. Wang, M. Farooq, L. Xue and S. Ali. 2011. Fulvic acid application improves the maize performance under well-watered and drought conditions. J. Agron. Crop Sci., 197: 409-417. https://doi.org/10.1111/j.1439037X.2011.00483.X

Brestic, M., M. Zivcak, K. Kunderlikova and S.I. Allakhverdiev. 2016. High temperature specifically affects the photoprotective responses of Chlorophyll b-deficient wheat mutant lines. Photosynth. Res., 130: 251-266. https://doi. org/10.1007/s11120-016-0249-7

Droux, M., 2004. Sulfur assimilation and the role of sulfur in plant metabolism: A survey. Photosynth. Res., 79: 331-348. https://doi. org/10.1023/B:PRES.0000017196.95499.11

Fernández-Martínez, J.M., B. Pérez-Vich and L. Velasco. 2010. Sunflower, In: Vollmann, J., Rajcan, I. (Eds.), Oil Crops. Handbook of Plant Breeding. 155-232. https://doi. org/10.1007/978-0-387-77594-4_6

Kaschuk, G., T.W. Kuyper, P.A. Leffelaar, M. Hungria and K.E. Giller. 2009. Are the rates of photosynthesis stimulated by the carbon sink strength of rhizobial and arbuscular mycorrhizal symbioses? Soil Biol. Biochem., 41: 1233-1244. https://doi.org/10.1016/j.soilbio.2009.03.005

Kelly, M., W.G. Giese, C. Velasco-Cruz, L. Lawson, S.Ma,M.Wright and B.Zoecklein. 2017. Effect of foliar nitrogen and sulfur on petit manseng (Vitis vinifera L.) grape composition. J. Wine Res., 28: 165-180. https://doi.org/10.1080/095 71264.2017 .1324774

Koubaa, M., H. Mhemdi, F.J. Barba, S. Roohinejad, R. Greiner and E. Vorobiev. 2016. Oilseed treatment by ultrasounds and microwaves to improve oil yield and quality: An overview. Food Res. Int., 85: 59-66. https://doi.org/10.1016/j. foodres.2016.04.007

Kumar,A.P.,A.Boualem,A.Bhattacharya,S.Parikh, N. Desai, A. Zambelli, A. Leon, M. Chatterjee and A.Bendahmane.2013.SMART-Sunflower Mutant population And Reverse genetic Tool for crop improvement. BMC Plant Biol., 13: 38. https://doi.org/10.1186/1471-2229-13-38

López-Bellido, L., R.J. López-Bellido and F.J. López-Bellido. 2006. Fertilizer Nitrogen Efficiency in Durum Wheat under Rainfed Mediterranean Conditions: Effect of Split
Application. Agron. J., 98: 55-62. https://doi. org/10.2134/agronj2005.0017

Montemurro, F., M. Maiorana, D. Ferri and G. Convertini. 2006. Nitrogen indicators, uptake and utilization efficiency in a maize and barley rotation cropped at different levels and sources of N fertilization. Field Crops Res., 99: 114124. https://doi.org/10.1016/j.fcr.2006.04.001

Murtaza, B., G. Murtaza, M. Sabir, M. Amjad and M. Imran. 2016. Nitrogen Management in Rice-Wheat Cropping System in SaltAffected Soils. In: K.R. Hakeem, J. Akhtar, and M. Sabir (eds.), Soil Science: Agricultural and Environmental Prospectives. Springer International Publishing, Cham. pp. 67-89. https://doi.org/10.1007/978-3-319-344515_3

Panković,D.,N.Radovanović,S.Jocić,Z.Satovic and D. ŠKorić. 2007. Development of co-dominant amplified polymorphic sequence markers for resistance of sunflower to downy mildew race 730. Plant Breed, 126: 440-444. https://doi. org/10.1111/j.1439-0523.2007.01376.x

Pattanayak, S., A.K. Behera, P. Das, M.R. Nayak, S.N. Jena and S. Behera. 2017. Performance of summer sunflower (Helianthus annuus L.) hybrids under different nutrient management practices in coastal Odisha. J. Appl. Nat. Sci., 9: 435-440. https://doi.org/10.31018/jans. v9i1.1209

Pružinská, A., G. Tanner, I. Anders, M. Roca and S. Hörtensteiner. 2003. Chlorophyll breakdown: Pheophorbide, an oxygenase, is a Rieske-type iron-sulfur protein encoded by the accelerated cell death 1 gene. Proc. Natl. Acad. Sci., 100: 15259-15264. https://doi.org/10.1073/ pnas.2036571100

Rao, D.N. and F. LeBlanc. 1966. Effects of sulfur dioxide on the lichen alga, with special reference to chlorophyll. Bryologist, 69: 69-75. https://doi.org/10.1639/00072745(1966)69[69:EOSDOT]2.0.CO;2

Seiler, G.J. 1992. Utilization of wild sunflower species for the improvement of cultivated sunflower. Field Crops Res. 30:195-230.

Semerci, A., Y. Kaya, Y. Kaya, I. Sahin and N. Citak. 2011. Evaluation of the changes in the cost factors of sunflower produced in thrace on the basis of the provinces in the research field and of the sizes of enterprise. Helia, 34: 147-158. https://doi.org/10.2298/HEL1154147S 
Shekhawat, K. and Y.S. Shivay. 2012. Residual effects of nitrogen sources, sulfur and boron levels on mungbean (Vigna radiata) in sunflower (Helianthus annuus), mungbean system. Arch. Agron. Soil Sci., 58: 765-776. https://doi.org/ 10.1080/03650340.2010.546786

Sher, A., M. Suleman, A. Qayyum, A. Sattar, A. Wasaya, M. Ijaz and A. Nawaz. 2018. Ridge sowing of sunflower (Helianthus annuus L.) in a minimum-till system improves the productivity, oil quality, and profitability on sandy loam soil under an arid climate. Environ. Sci. Pollut. Res., 25: 11905-11912. https://doi.org/10.1007/ s11356-018-1336-4

Steel, R.G.D. and J.H. Torrie. 1980. Principles and procedures of statistics, a biometrical approach. Princ. Proceed. Stat. Biom. Approach.

Uz-Zaman, B., A. Ali, M. Arshadullah, J. Ud-Din, M. Suhaib, M. Yousra and S. Ahmed. 2018. Growth Response of Sunflower to Potassium
Sulphate Application in Saline-sodic Soil. Asian J. Res. Agric. For., pp. 1-7. https://doi. org/10.9734/AJRAF/2018/42238

Wolf, B., 1982. A comprehensive system of leaf analyses and its use for diagnosing crop nutrient status. Commun. Soil Sci. Plant Anal., 13: 1035-1059. https://doi. org/10.1080/00103628209367332

Wong, J.W.C., K.K. Ma, K.M. Fang and C. Cheung. 1999. Utilization of manure compost for organic farming in Hong Kong. Bioresour. Technol., 67: 43-46. https://doi.org/10.1016/ S0960-8524(99)00066-8

Wu, S.C., Z.H. Cao, Z.G. Li, K.C. Cheung and M.H. Wong. 2005. Effects of biofertilizer containing $\mathrm{N}$-fixer, $\mathrm{P}$ and $\mathrm{K}$ solubilizers and AM fungi on maize growth: A greenhouse trial. Geoderma, 125: 155-166. https://doi. org/10.1016/j.geoderma.2004.07.003 